\title{
Report on Copyright and HEA Amendments
}

On April 7, 1976, the House Judiciary Subcommittee on Courts, Civil Liberties and the Administration of Justice marked up the Copyright Revision Bill (HR 2223), taking action on section $108(\mathrm{~g})(2)$, the section dealing with photocopying in libraries. The position of the six professional library associations, the American Library Association, the Association of Research Libraries, the American Association of Law Libraries, the Medical Library Association, the Music Library Association, and the Special Libraries Association, which asked for the deletion of the photocopying restriction, was discussed as well as the position of the copyright proprietors. Members of the subcommittee frequently mentioned during the mark-up session the number of librarians who had written them on this issue and the solidarity of the library point of view. An amendment to section $108(\mathrm{~g})(2)$ was introduced by Chairman Robert Kastenmeier (D-Wis.) and approved by voice vote of the members of the subcommittee. The language of the amendment follows with new wording underscored.

$108(\mathrm{~g})$ The rights of reproduction and distribution under this section extended to the isolated and unrelated reproduction or distribution of a single copy or phonorecord of the same material on separate occasions, but do not extend to cases where the library or archives, or its employee:

(1) is aware or has substantial reason to believe that it is engaging in the related or concerted reproduction or distribution of multiple copies or phonorecords of the same material, whether made on one occasion or over a period of time, and whether intended for aggregate use by one or more individuals or for separate use by the individual members of a group; or

(2) engages in the systematic reproduction or distribution of single or multiple copies or phonorecords of material described in subsection (d); provided that nothing in this clause prevents a library or archives from participating in interlibrary arrangements that do not have, as their purpose or effect, that the library or archives re-

Continued on page 155

\section{Renewable Resources Program for ABSS}

The Agriculture and Biological Sciences Section of the Association of College and Research Libraries of the American Library Association is pleased to announce that they will have Dr. Robert Z. Callaham, director of forest environment research in the U.S. Forest Service, as a guest speaker for their annual meeting on Wednesday, July 21, 1976, to be held at the Museum of Science and Industry during the ALA Annual Conference. Dr. Callaham is responsible for the creation and emergence of the Renewable Resource Technical Information System presently being developed by the U.S. Forest Service and its cooperators. He has been an editor of Silva Genetica and is now divisional coordinator of forest plants and forest protection for the International Union of Forestry Research Organizations.

Dr. Callaham's presentation will consider the Renewable Resource Technical Information System in terms of local, state, federal, and international cooperation; the present and future capabilities in information analysis and document delivery within the system; the role of libraries in an information network for forestry. A selected panel of librarians will interact with
Dr. Callaham's presentation and field questions from the audience.

Advance tickets will be $\$ 7.00$ for the program, luncheon, business and membership meeting of the section, a tour of the Museum of Science and Industry, and round-trip bus transportation. To obtain tickets, mail a stamped self-addressed envelope and your check made out to the American Library Association to: Linnea Sodergren, 1401 E. 55th St. \#314N, Chicago, IL 60615. This all-day program is open to all but limited to the first 100 people making paid reservations; tickets may be transferred to another individual but are nonrefundable. Any remaining tickets may be available at the Meal Ticket Desk beginning on Friday, July 16, during the Annual Conference through 9:30 a.m. on Monday, July 19. Buses will depart for the museum promptly at $9: 30$ a.m. on Wednesday, July 21 from the State Street side of the Palmer House, picking up other participants directly thereafter at the Eighth Street side of the Conrad Hilton. Return buses will leave at 3:30 p.m. from the museum to return to both downtown stops. 